\title{
Toward a General Theory of Boundary Work: Insights from the CGIAR's Natural Resource Management Programs
}

\section{Citation}

Clark, William C., Thomas P. Tomich, Meine van Noordwijk, Nancy M. Dickson, Delia Catacutan, David Guston, and Elizabeth McNie. 2010. Toward a General Theory of Boundary Work: Insights from the CGIAR's Natural Resource Management Programs. HKS Faculty Research Working Paper Series RWP10-035, John F. Kennedy School of Government, Harvard University.

\section{Published Version}

http://web.hks.harvard.edu/publications/workingpapers/citation.aspx?Publd=7389

\section{Permanent link}

http://nrs.harvard.edu/urn-3:HUL.InstRepos:4450046

\section{Terms of Use}

This article was downloaded from Harvard University's DASH repository, and is made available under the terms and conditions applicable to Other Posted Material, as set forth at http:// nrs.harvard.edu/urn-3:HUL.InstRepos:dash.current.terms-of-use\#LAA

\section{Share Your Story}

The Harvard community has made this article openly available.

Please share how this access benefits you. Submit a story.

Accessibility 


\title{
Toward a General Theory of Boundary Work: I nsights from the CGI AR's Natural Resource Management Programs Faculty Research Working Paper Series
}

\author{
William C. Clark \\ Harvard Kennedy School
}

Thomas P. Tomich

University of California at Davis

Meine van Noordwijk

World Agroforestry Centre

Nancy M. Dickson

Harvard Kennedy School

Delia Catacutan

World Agroforestry Centre

David Guston

Arizona State University

Elizabeth McNie

Purdue University

\section{September 2010 RWP10-035}

The views expressed in the HKS Faculty Research Working Paper Series are those of the author(s) and do not necessarily reflect those of the John F.

Kennedy School of Government or of Harvard University. Faculty Research Working Papers have not undergone formal review and approval. Such papers are included in this series to elicit feedback and to encourage debate on important public policy challenges. Copyright belongs to the author(s). Papers may be downloaded for personal use only. 


\title{
Toward a general theory of boundary work: Insights from the CGIAR's natural resource management programs
}

\author{
Authors: \\ William C. Clark ${ }^{1}$, Thomas P. Tomich ${ }^{2}$, Meine van Noordwijk ${ }^{3}$, \\ Nancy M. Dickson ${ }^{1}$, Delia Catacutan ${ }^{4}$, David Guston ${ }^{5}$, Elizabeth McNie ${ }^{6}$ \\ ${ }^{1}$ John F. Kennedy School of Government, Harvard University, Cambridge, MA, USA \\ ${ }^{2}$ Agricultural Sustainability Institute, University of California at Davis, CA, USA \\ ${ }^{3}$ World Agroforestry Centre, Bogor, Indonesia \\ ${ }^{4}$ World Agroforestry Centre, Nairobi, Kenya \\ ${ }^{5}$ Consortium for Science, Policy and Outcomes at Arizona State Univ., Tempe, AZ, USA \\ ${ }^{6}$ Department of Political Science, Purdue University, West Lafayette, IN, USA
}

Sustainability Science Program, Harvard Kennedy School of Government

CID Working Paper No. 199

July 2010

(C) Copyright 2010 William C. Clark et al. and the President and

Fellows of Harvard College

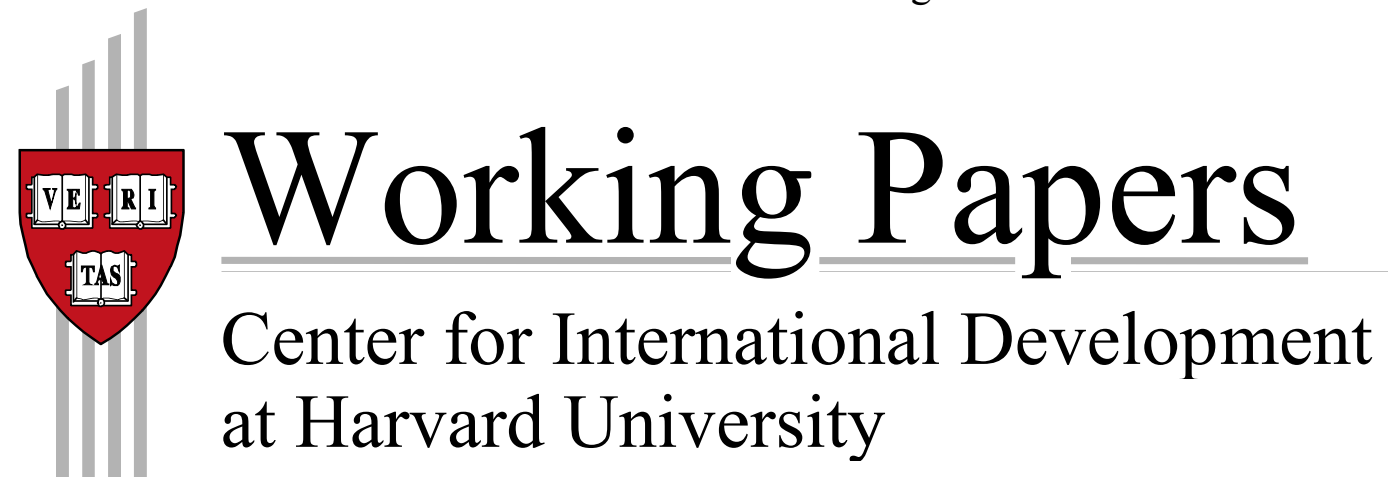




\begin{abstract}
Previous research on the determinants of effectiveness in knowledge systems seeking to support sustainable development has highlighted the importance of "boundary work" through which research communities organize their relations with other fields of science, other sources of knowledge, and the worlds of action and policymaking. A growing body of scholarship postulates specific attributes of boundary work that promote used and useful research. These propositions, however, are largely based on the experience of a few industrialized countries. We report here on an effort to evaluate their relevance for efforts to harness science in support of sustainability in the developing world. We carried out a multi-country comparative analysis of natural resource management programs conducted under the auspices of the Consultative Group on International Agricultural Research (CGIAR). We discovered 6 distinctive kinds of boundary work contributing to successes of the CGIAR programs - a greater variety than has been documented in previous studies. We propose that these different kinds of boundary work can be understood as a dual response to the different uses for which the results of specific research programs are intended, and the different sources of knowledge drawn on by those programs. We show that these distinctive kinds of boundary work require distinctive strategies to organize them effectively. Especially important are arrangements regarding participation of stakeholders, governance, and the use of boundary objects. We conclude that improving the ability of research programs to produce useful knowledge for sustainable development will require both greater and differentiated support for multiple forms of boundary work.
\end{abstract}

Keywords: boundary work, boundary organizations, boundary objects, agroforestry systems, governance, participation, sustainability science, sustainable development, environmental policy

\title{
JEL subject codes: Q01, Q15, Q2, Q56
}

This paper may be cited as: Clark, William C., Thomas P. Tomich, Meine van Noordwijk, Nancy M. Dickson, Delia Catacutan, David Guston, and Elizabeth McNie. 2010. Toward a general theory of boundary work: Insights from the CGIAR's natural resource management programs. CID Working Paper No. 199. Center for International Development, Harvard University. Cambridge, MA: Harvard University, July 2010. It is available at http://www.hks.harvard.edu/centers/cid/publications/faculty-working-papers/cid-working-paperno.-199. Comments are welcome and should be directed to: william_clark@harvard.edu. 


\section{The Sustainability Science Program at Harvard University}

The Sustainability Science Program at the Center for International Development harnesses Harvard University's strengths to promote the design of institutions, policies, and practices that support sustainable development. The Program addresses the challenge of sustainable development by: advancing scientific understanding of human-environment systems; improving linkages between research and policy communities; and building capacity for linking knowledge with action to promote sustainability. The Program supports major initiatives in policy-relevant research, faculty research, training of students and fellows, teaching, and outreach. Further information is available though the Program web site at www.cid.harvard.edu/sustsci/, or from co-Directors William C. Clark (william_clark@harvard.edu or Nancy Dickson (nancy_dickson@harvard.edu), at the Center for International Development, Harvard Kennedy School, 79 JFK Street, Cambridge, MA 02138 USA.

\section{Author Acknowledgements}

We acknowledge with gratitude the numerous groups that have provided financial and institutional support. Initial financial support for the project, "Harnessing Science and Technology for Sustainability" referred to as the "Knowledge Systems for Sustainable Development" project was provided by the National Oceanic and Atmospheric Administration's Environment, Science and Development Program (formerly the Office of Global Programs).

Supplemental support was provided by a grant for the "Integrated Knowledge and Policy for the Management of Natural Resources in International Development: The Role of Boundary Organizations" project by the National Science Foundation (award SES-0621004). Institutional support has been provided by the Sustainability Science Program at the Center for International Development at Harvard University; the Alternative to Slash and Burn Program of the Consultative Group for International Agriculture Research; the Rewarding Upland Poor for Environmental Services (RUPES) program of the World Agroforestry Centre in Bogor, Indonesia and Nairobi, Kenya; and the Consortium for Science, Policy and Outcomes at Arizona State University.

We owe special thanks to several people: Patti Kristjanson at the World Agroforestry Center (formerly at the International Livestock Research Institute); Robin Reid, Colorado State University (formerly at the International Livestock Research Institute) and from Niken Sakuntaladewi, Suyanto, Laxman Joshi, Beria Leimona, Kurniatun Hairiah, and Noviana Khususiyah, all from World Agroforestry Center in Bogor, Indonesia. We also thank Nora O'Neil and Mary Anne Baumgartner, Program Manager and Assistant for the Sustainability Science Program for their administrative support of these projects. The views expressed in this paper are those of the authors and do not necessarily reflect those of the Sustainability Science Program, of the Center for International Development, or of Harvard University. The CID Faculty Working Papers have not undergone formal review and approval. Such papers are included in this series to elicit feedback and to encourage debate on important public policy challenges. Copyright is retained by the authors. Papers may be downloaded for personal use only. 


\section{Table of Contents}

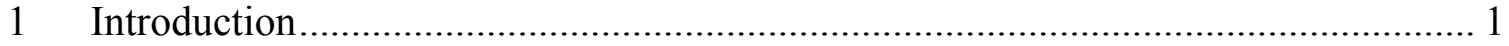

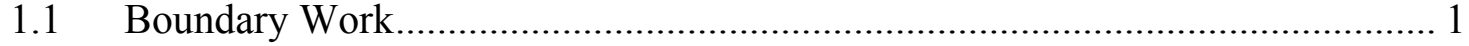

1.2 Natural Resource Management at the CGIAR .................................................. 2

2 Varieties of Boundary Work: A Conceptual Framework .......................................... 3

3 Use of Knowledge for Enlightenment (Uo) ........................................................ 4

3.1 Boundaries between New Discoveries and Established Knowledge $\left(\mathrm{S}_{1} \mathrm{U}_{\mathrm{o}}\right) \ldots \ldots .5$

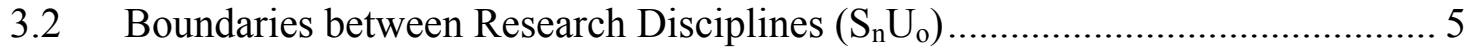

3.3 Boundaries between Context-Specific and Generalizable Research $\left(\mathrm{S}_{\mathrm{n}} \mathrm{U}_{\mathrm{o}}\right) \ldots \ldots \ldots$

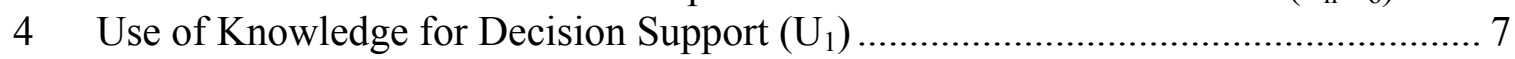

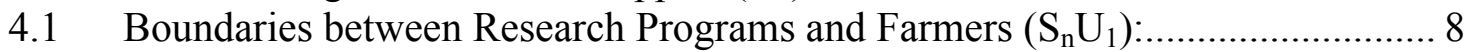

4.2 Boundaries between Research Programs and National Policy Makers $\left(\mathrm{S}_{1} \mathrm{U}_{1}\right) \ldots .9$

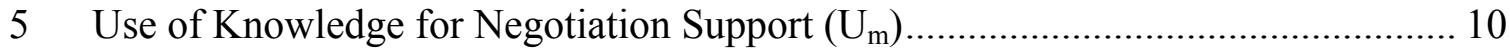

5.1 Boundaries between the ASB and Multinational Negotiations $\left(\mathrm{S}_{1} \mathrm{U}_{\mathrm{m}}\right) \ldots \ldots \ldots \ldots . . . .10$

5.2 Boundaries between Multiple Knowledge Sources and Multiple Users $\left(\mathrm{S}_{\mathrm{n}} \mathrm{U}_{\mathrm{m}}\right) 12$

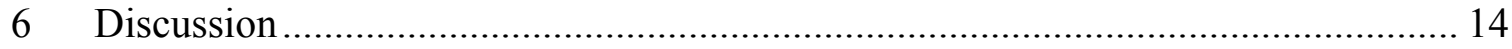

6.1 Differentiated Challenges of Boundary Work ............................................. 14

6.2 Differentiated Strategies of Boundary Work ................................................ 15

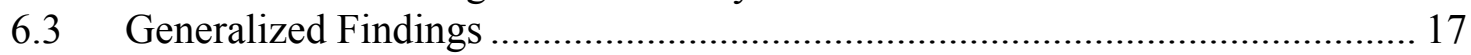

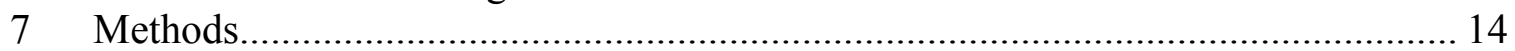

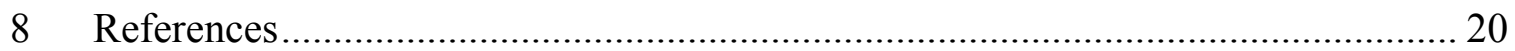




\section{Introduction}

Sustainable development—development that promotes human well-being while conserving the earth's life support systems - is a knowledge intensive endeavor. Efforts to improve linkages among research programs, experiential knowledge and action on the ground have nonetheless been spotty. The question that concerns an increasing number of scientists, program managers and donors is therefore not whether but rather how to modify program design and practice in ways that help to realize the great potential of research programs to support sustainable development (ICSU, ISTS, TWAS 2002; World Bank 1998).

\subsection{Boundary Work}

Previous research has suggested that the concept of "boundary work" provides one potentially powerful leverage point for designing research programs that better link knowledge with action for sustainability (Cash et al. 2003). "Boundary work" signifies the processes through which the "research community organizes its relations with the worlds of action and policy making" (Hellstrom and Jacob 2003, 235) on the one hand, and with practice-based and other forms of knowledge on the other. Originally developed to help understand efforts to demarcate "science" from "non-science" (Gieryn 1983; Evans 2005), the idea of boundary work has since been applied to the interface between science and policy (Jasanoff 1990; Guston 2001) and, more broadly, to the activities of organizations that seek to mediate between knowledge and action (Cash et al. 2003).

The central idea of boundary work is that tensions arise at the interface between actors with different views of what constitutes reliable or useful knowledge, and that those tensions must be managed effectively if the potential benefits of research-based knowledge are to be realized by society. Too little permeability of the boundaries separating science from the world of action means too little learning from or contribution to practice. Dissolve the boundary entirely, however, and not only does science risk being politicized, but politics and politicians risk being viewed as mere mouthpieces of the technocracy (Guston 2001; Jones et al. 2008, sect. 3.1.1). Active boundary work is therefore required to manage effectively the interfaces among various stakeholders engaged in harnessing knowledge to promote action (Jasanoff 1990).

How can the "effectiveness" of boundary work be evaluated? This is a difficult question. It has nonetheless been illuminated by a growing body of research suggesting that technical information in policy contexts is more likely to be influential to the extent that it is perceived by multiple stakeholders as satisfying the salience, credibility, and legitimacy, "SCL," criteria summarized in Table 1 (Mitchell et al. 2006; NRC 2007). In this paper, we build on recent work applying the SCL criteria to evaluate the effectiveness of boundary work (Jones et al. 2008; Mollinga 2008). 
Table 1: SCL criteria for evaluating the effectiveness of boundary work

\begin{tabular}{|l|l|}
\hline Criterion & \multicolumn{1}{|c|}{ Concerns addressed } \\
\hline Saliency & Is it relevant or valuable for the decision or policy in question? \\
\hline Credibility & Is it true or technically adequate in its handling of evidence? \\
\hline Legitimacy & Is it fair, unbiased, and respectful of stakeholders? \\
\hline
\end{tabular}

Scholarship on boundary work has expanded greatly in recent years, as evidenced by the number of special features devoted to the topic in a wide range of journals (Guston 2001; Hellstrom and Jacob 2003; Evans 2005; Raman 2005). Despite differences in emphasis and language, this research postulates that boundary work is more likely to be effective in promoting used and useful research to the extent that it exhibits three key attributes: i) meaningful participation in agenda setting and knowledge production by stakeholders from all sides of the boundary; ii) governance arrangements that render the resulting boundary work accountable to relevant stakeholders; and iii) the production of "boundary objects" (collaborative products such as maps or models or reports that "are both adaptable to different viewpoints and robust enough to maintain identify across them" (Star and Grieshemer 1989, 387)).

There remain, however, two concerns with these widely shared generalizations. First, most of the empirical evidence on which they are based derives from case studies of single local or national efforts to link research knowledge with action. Most of those cases are confined to relatively simple situations in a few countries of Europe and North America. Conclusions extracted from this limited data set are nonetheless increasingly being used to guide the reform of research systems for sustainability in the developing world. Second, even where there is some agreement on the properties that characterize effective boundary work, there is much less on which strategies for organizing boundary work are most likely to yield such properties in particular circumstances (Jones et al. 2008).

\subsection{Natural Resource Management at the CGIAR}

The research reported here sought to address the concerns noted above through the comparative analysis of boundary work in family of programs on integrated natural resource management (iNRM) carried out under the auspices of the Consultative Group on International Agricultural Research (CGIAR): one of the world's largest and most experienced global research organizations seeking to foster sustainability in the developing world (CGIAR 2008). Within the CGIAR, we focused on boundary work conducted within the "Partnership for Tropical Forest Margins" (formerly called the "Alternatives to Slash and Burn" program, and still known by the acronym ASB). The ASB describes itself as "a global partnership of research institutes, non-governmental 
organizations, universities, community organizations, farmers' groups, and other local, national, and international organizations... ASB's goal is to raise productivity and income of rural households in the humid tropics without increasing deforestation or undermining essential environmental services..." (ASB 2010). The ASB program has been operating since 1994 in 10 benchmark sites around the world covering the Amazon, the Congo Basin, northern Thailand, Mindanao, and Sumatra (Palm et al. 2005). As recognized by its receipt of the CGIAR's Science Award, ASB has been involved in some of the world's most innovative efforts to link knowledge with action in support of sustainable development. Lessons drawn from its experience with boundary work should thus have wide applicability.

We have published elsewhere detailed accounts of how the ASB program has functioned and of its impacts on both knowledge and action relevant to sustainable development (Tomich et al. 2007; Clark et al. 2006). Here we reanalyze data presented in those publications and supplement it with new field work from Indonesia and the findings of a pair of targeted workshops to explore two much more specific questions:

- To what extent does ASB's history of efforts to link knowledge with action for sustainable development of tropical forest margins confirm, reject, or call for extension of existing generalizations about the attributes of successful boundary work?

- What does the ASB experience have to say about how local context shapes the challenges facing boundary work, and thus the strategies for carrying it out effectively?

\section{Varieties of Boundary Work: A Conceptual Framework}

We discovered two big things from our exploration of boundary work in the natural resource management programs of the CGIAR/ASB. First, we encountered a far greater variety of boundary work and strategies for pursuing it than the literature had led us to expect. Second, we determined that much of that variety - and the success of strategies that produce it — can be understood in terms of the sources and uses of the knowledge that boundary work engages. In particular, we found that the conceptual framework suggested in Table 2 allowed us to make sense of the complex ASB experience. (We argue in the Discussion section of this paper that the framework is general, accommodating and relating other cases of boundary work described in the literature.)

The columns of the framework address the uses of knowledge, i.e., the purpose for which users deploy knowledge. Drawing on the literature of policy science (e.g., Lindblom and Cohen 1979), we distinguish use for i) enlightenment, or the advancement of general understanding in the (relative) absence of significant decision consequences [ $\left.\mathrm{U}_{\mathrm{o}}\right]$; ii) decision support of choices made by a single relatively autonomous user such as a farmer or minister $\left[\mathrm{U}_{1}\right]$; and iii) negotiation support of bargaining or other political interactions among multiple users $\left[\mathrm{U}_{\mathrm{m}}\right]$. The rows of the framework address the sources of new knowledge. We distinguish between i) knowledge that is seen by users as originating with a single, authoritative source $\left[\mathrm{S}_{1}\right]$; and ii) knowledge that is seen by users as originating with multiple potentially conflicting sources $\left[\mathrm{S}_{\mathrm{n}}\right]$. (A more general version 
of the typology presented here would add an additional row $\left[\mathrm{S}_{\mathrm{o}}\right]$ at the top of the framework, representing knowledge that is seen by a potential users such as farmers or policy makers to originate in their own direct experience. But though such selfknowledge may be generally important, it is not central to the questions asked in this study. For simplicity, we have therefore left it out of the framework used here.) The individual cells of the framework reflect how the particular combinations of knowledge sources and uses determine the challenges facing boundary work in particular contexts. The arrows in Table 2 represent the potential for two-way interactions among the relevant sources and users of knowledge. (Whether those interactions actually take place, and the extent to which they are balanced rather than biased in direction, are empirical questions to be answered for particular cases). Material is presented in terms of the three uses of knowledge reflected in the columns of the Table.

Table 2: Varieties of boundary work

\begin{tabular}{|c|c|c|c|c|}
\hline \multicolumn{2}{|c|}{ Boundary Work } & \multicolumn{3}{|c|}{ USE of knowledge to support.... } \\
\hline & undary Work & $\begin{array}{c}\text { Enlightenment } \\
\left(\mathbf{U}_{0}\right)\end{array}$ & $\begin{array}{c}\text { Decision } \\
\left(\mathbf{U}_{1}\right)\end{array}$ & $\begin{array}{c}\text { Negotiation } \\
\left(\mathbf{U}_{\mathbf{m}}\right)\end{array}$ \\
\hline \multirow{2}{*}{ 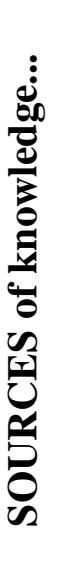 } & $\begin{array}{c}\text { Single external } \\
\text { expert } \\
\left(\mathbf{S}_{1}\right)\end{array}$ & $\begin{array}{c}\mathrm{S}_{1} \leftrightarrow \mathrm{U}_{\mathrm{o}} \\
\text { (Demarcation) }\end{array}$ & $\begin{array}{c}\mathrm{S}_{\mathrm{i}} \leftrightarrow \mathrm{U}_{\mathrm{j}} \\
(\text { Expert advice })\end{array}$ & $\begin{array}{c}\mathrm{U}_{\mathrm{k}} \\
\mathrm{S}_{\mathrm{i}} \leftrightarrow \underset{\downarrow}{\mathrm{U}_{\mathrm{l}}} \\
\text { (Assessment) }\end{array}$ \\
\hline & $\begin{array}{c}\text { Multiple } \\
\text { external experts } \\
\left(\mathbf{S}_{\mathbf{n}}\right)\end{array}$ & $\begin{array}{c}\mathrm{S}_{\mathrm{i}} \\
\uparrow \leftrightarrow \mathrm{U}_{\mathrm{o}} \\
\mathrm{S}_{\mathrm{j}} \\
\text { (Integrative/ } \\
\text { interdisciplinary } \\
\mathrm{R} \& \mathrm{D} \text { ) }\end{array}$ & $\begin{array}{c}\mathrm{S}_{\mathrm{i}} \\
\uparrow \leftrightarrow \mathrm{U}_{\mathrm{j}} \\
\mathrm{S}_{\mathrm{j}} \\
\text { (Participatory / } \\
\text { Farming systems } \\
\mathrm{R} \& \mathrm{D} \text { ) }\end{array}$ & $\begin{array}{c}\mathrm{S}_{\mathrm{i}} \quad \mathrm{U}_{\mathrm{k}} \\
\uparrow \leftrightarrow \uparrow \\
\mathrm{S}_{\mathrm{j}} \quad \mathrm{U}_{\mathrm{l}} \\
\text { (Political } \\
\text { bargaining) }\end{array}$ \\
\hline
\end{tabular}

\section{Use of Knowledge for Enlightenment (Uo)}

The simplest boundary work we found in ASB occurred in the context originally addressed by Gieryn's seminal work on the topic: where the relevant user is the research community itself (in this case ASB), looking on new information primarily as a source of enlightenment, with no immediate concerns for application in the world of action (i.e., in column $\mathrm{U}_{\mathrm{o}}$ in Table 2). The central challenge for ASB's boundary work in this enlightenment context was to meet the "credibility" criterion of the SCL framework shown in Table 1: sorting new knowledge claims into those that are accepted into the body of accepted scientific fact and those that are not. If the boundary regulating such acceptance is too impermeable, new findings and ideas can gain no traction with the 
research community and understanding cannot grow. If the boundary is too permeable, solid facts and idiosyncratic experience and mere conjecture get so mixed as to undermine the knowledge foundations on which further research tries to build deeper understanding of the world.

\subsection{Boundaries between New Discoveries and Established Knowledge $\left(S_{1} U_{0}\right)$}

The ASB program addressed the same challenge facing all research communities of deciding whether to accept a particular new research result into its body of accepted, reliable knowledge (cell $\mathrm{S}_{1} \mathrm{U}_{\mathrm{o}}$ in Table 2). For much of its research, ASB confronted this conventional boundary work challenge with conventional processes for quality control such as significance tests and standards for experimental replicability. We found, not surprisingly, that the ASB research programs dealt quite well with these normal "peer review" activities (Clark et al. 2006).

\subsection{Boundaries between Research Disciplines $\left(\mathrm{S}_{\mathbf{n}} \mathrm{U}_{\mathbf{0}}\right)$}

More challenging were the circumstances in which ASB sought to stimulate the production and integration of expertise from multiple sources of knowledge, often involving multiple methods or rules of evidence (cell $\mathrm{S}_{\mathrm{n}} \mathrm{U}_{\mathrm{o}}$ in Table 2). The ASB work characterized by this cell confronted two distinct challenges of boundary work, and developed distinctive and original strategies for dealing with them.

ASB leadership recognized early on that understanding the sustainability of alternative human land uses at the tropic forest margins would require the integration of research across the natural and social sciences (Tomich et al. 2007). Such integration, however, posed significant challenges for the program, embedded as it was in the traditionally natural science culture of the CGIAR. The initial temptation of the natural scientists who dominated the early ASB was simply to "do their best" at addressing complex social structure and incentive issues they encountered at their field sites. This approach, however, was quickly seen to produce mediocre research and to threaten the credibility of the entire program. Differences among disciplines in rules of evidence and jargon, plus an initial lack of mutual respect between natural and social scientists, made the creation of knowledge judged to be credible by all seem almost beyond reach. As the program matured, however, the successful strategies that did emerge exhibited most of the attributes, noted earlier, that the literature led us to expect.

Participation: The joint participation of both natural and social scientists in integrated research efforts was initially achieved by issuing contracts for them to participate in problem-focused "thematic working groups" especially that devoted explicitly to "Synthesis and linkages." "Safe spaces" (NRC 2006) that encouraged two-way communication among participants across disciplines were created through the program's use of joint field trips to the ASB benchmark research sites. The "retreat-like" character of these field visits were widely cited by participants as extremely powerful mechanisms for fostering more meaningful and respectful exchanges across the gulf normally separating natural and social science researchers (Tomich et al. 2007). 
Accountability: The central governance challenge in this context was to assure that the ASB agenda was not captured by either natural or social scientists. Such mechanisms were not as formal or strong as they might have been at ASB, especially during the early stages of the program. The presence on the program's original Global Steering Group of international partner institutions with a relatively strong commitment to social science perspectives almost certainly provided an important counterbalance to CGIAR's natural science biases in the early stages of the program.

Boundary Objects: Tangible evidence of successful boundary work in the ASB's efforts to build multidisciplinary research approaches lies primarily in a variety of boundary objects reflecting inputs from both natural and social science participants. One of the first of these was the development of shared standards and protocols for data collection developed to guide and coordinate work across the ASB benchmark sites. There was little truly interdisciplinary scholarship involved in this work. But the commitment of natural and social scientists to contribute their respective parts to a common whole clearly advanced mutual understanding and respect. Real interdisciplinary integration followed, perhaps most clearly illustrated by the bio-economic models developed by ASB and its partners from Brazil's Embrapa. These models, with significant social and natural science input, managed to elucidate links among the introduction of new technologies such as large scale mulching and high yield rice, the spread of those innovations among adopters, and the eventual impacts on deforestation. The models came to serve ASB researchers as a widely cited and emulated illustration of the potential benefits of true interdisciplinary integration, creating products judged to be credible by both natural and social scientists.

\subsection{Boundaries between Context-Specific and Generalizable Research $\left(S_{n} U_{0}\right)$}

A second knowledge systems challenge confronted by ASB from its inception was the integration of research conducted by scientists from its "national" and "international" networks. Too often, "global" research programs end up with agendas set and publications authored by what Merton $(1957,387)$ called "cosmopolitan" researchers drawing from their international networks, while "local" scholars-largely based in national institutions in the developing world - are relegated to tasks of running the experiments and collecting the data. Moreover, ASB like all CGIAR centers faced the broader but related challenge of integrating research focused on generalizable results with research emphasizing context-specific understanding and solutions.

The key to effective boundary work for addressing these tensions in the ASB turned out to be primarily the Program's commitment to do so. It developed a set of operating principles that made full partnerships between local and international researchers the touchstone of all ASB activities.

Participation: The principles highlighted the commitment of the program to full participation of all researchers in agenda setting, resource allocation, and credit for findings and publications. Full transparency of decisions and decision making was also emphasized. 
Accountability: Governance provisions to assure that these goals were in fact achieved came through representation of both local and international researchers on the program's "Steering Group," with a preference for national partners. Success of the program's commitment to shared credit and authorship is well documented (Clark et al. 2006) and conspicuous in its principal summary publication (Palm et al. 2005).

Boundary Objects: The most important "boundary objects" created in the work of mediating between norms of context-specific and generalizable research was the program's decision to create and use of its benchmark sites for the study of human use of forest margins throughout the humid tropics. Each site developed a research program tuned to local needs and capacities, but also committed to exploring certain common question and to using some common methods, metrics, and protocols.

\section{Use of Knowledge for Decision Support $\left(U_{1}\right)$}

ASB's research was designed to pursue the same overall objective as all CGIAR/iNRM programs: "incorporating multiple aspects of natural resource use into a system of sustainable management to meet explicit production goals of farmers and other users..." (CGIAR Task Force on NRM 2000, 5). Much of its activity therefore took place at the interface between basic research and policy application, and grappled with the associated boundary work challenges initially identified by Jasanoff (1990) and Guston (2001). We found, however, that the challenges addressed by such boundary work were radically different depending on whether the "user" was a single, relatively autonomous decision maker (column $\mathrm{U}_{1}$ in Table 2) or a more complex political negotiation among multiple political interests $\left(\mathrm{U}_{\mathrm{m}}\right)$. We address the latter case in the next section. Here we focus on the use of knowledge for simple "decision support" (col. $\left.U_{1}\right)$.

The challenge for ASB's boundary work that was intended to mediate the use of knowledge for decision support $\left(\mathrm{U}_{1}\right)$ was more complex than its principal use was to foster enlightenment alone $\left(\mathrm{U}_{\mathrm{o}}\right)$. In particular, in terms of the SCL concepts of Table 1, for knowledge to be useful in support of decision making, it needed to be perceived as not only scientifically credible but also as salient or relevant to decision makers' needs. An insufficiently permeable boundary between research and decision making meant that scientists would continue to set their research priorities on the basis of what they imagined decision makers wanted to know rather than learning from them what they actually need, while decision makers would remain ignorant of what good R\&D might realistically have to offer. An overly permeable boundary, in contrast, risked both the politicization of science and the scientization of politics. In the first case, decision makers look for research primarily to support decisions they have already made. In the latter, decision makers avoid responsibility for grappling publicly with fundamental questions of "who-gets-what" by repackaging them as "merely" technical issues to be resolved by experts who they happen to control. 
In our investigations of ASB, we found two distinctive types boundary work being carried out to address these challenges of harnessing science for decision support, one between scientists and farmers, the other between scientists and policy-makers.

\subsection{Boundaries between Research Programs and Farmers $\left(S_{n} U_{1}\right)$ :}

Early work by the CGIAR on linking research with action by farmers had employed a largely one-directional "extension" model of technology transfer. By the time ASB was organized in the 1990s, the shortcomings of this approach were widely recognized. These included its failure to integrate farmers' with researchers' knowledge, and its tendency to define agendas in terms of researchers' solutions rather than farmers' problems. Much progress had been made toward adopting a bi-directional, collaborative model of "farming systems research" and development. ASB enthusiastically adopted this model, but nonetheless struggled to shape the boundary work needed to implement it successfully. We summarize below what we learned from the program's experience.

Participation: Scientists and farmers did participate in joint priority setting, research, and evaluation activities at most ASB sites. These partnerships were largely informal and opportunistic, often triggered by outsiders' visits associated with project funding cycles or evaluations. Nonetheless, they generally succeeded in developing trust and rapport and almost certainly resulted in changes in both research agendas and the uptake of new findings. Scientists participated in these partnerships partly on the basis of their perception of the value of local knowledge in their research but also in response to the formal commitment by ASB that its work would be "grounded in local reality through long term engagement with farmers and community groups." Farmers participated for a variety of reasons, ranging from interest in scientific findings to the expectation that participation in the research activities would lead to major development projects. This latter expectation was generally frustrated, given the ASB's (and, more generally, the CGIAR's) status as an organization funded to do research, not to provide aid. Farmers nonetheless remained committed participants in the ASB work.

Accountability: Formal mechanisms to hold ASB's "farming systems research" accountable to both farmers and scientists were rare, generally occurring only when required by a particular funding arrangement. Much more common were informal consultations, often conducted in the context of field trips and site visits. ASB's unilateral commitment to utilizing participatory research methods was the prime mechanism we observed to guarantee farmers an opportunity for voicing dissatisfaction with the direction of ASB activities.

Boundary Objects: The joint production of products by scientists and farmers played a significant role in linking research with action at the ASB sites. Maps and physical models of relevant landscapes were the most valued knowledge products, though collaboratively conceived and conducted field trials were also important. More tangible boundary objects that anchored researcher-farmer collaboration included on-farm nurseries, the creation of improved plant varieties, and the production of training materials on effective new land use practices. 


\subsection{Boundaries between Research Programs and National Policy Makers $\left(\mathbf{S}_{\mathbf{1}} \mathbf{U}_{\mathbf{1}}\right)$}

Governments in the humid tropical regions addressed by ASB looked to the program for scientific information that would help them to manage alternative uses of land resources at the forest margin. ASB encountered two big challenges. First, the initial impetus for the program had come in large part from international environmental advocates who framed the problem as deforestation, the cause as slash-and-burn land use by smallholder farmers, and the solution as the development of alternatives to such practices (Sanchez et al. 2005). ASB's early work showed that this initial top-down framing was at odds with both scientific findings and decision realities on the ground. It sought to move beyond the initial top (global)-down framing imposed on it toward a more contextualized, bottom(national and regional)-up effort empowering local decision makers to help set locally salient (relevant) research priorities. Second, many of the scientists working on ASB's problems at the local level were employed by national ministries or international NGOs with strong political agendas of their own. This relationship often called into question the local scientists' ability to conduct, or be seen to conduct, truly independent and credible research. In these cases, ASB's principal challenge was to strengthen boundaries separating these scientists' research from their employers' politics. ASB experimented with a variety of strategies for creating research that would support better decisions by policy makers. We summarize below the approaches most often associated with success, organized in terms of key attributes of boundary work suggested in the literature.

Participation of scientists and policy makers in formal joint discussions about key decision-support priorities to be addressed by ASB research was never regularized. Rather, it occurred intermittently and often informally at meetings, workshops, and symposia driven by specific policy or research program opportunities. Significantly, however, the capacity to recognize and take advantage of such opportunities depended crucially on the development of sustained collegial relationships between senior program scientists and policy makers. These were fostered formally in Indonesia, where ASBunder the auspices of the CGIAR - maintained a small office within the Ministry of Forestry. Informal engagement was also effective, notably in Brazil and Thailand and sometimes in Peru and the Philippines. Such engagement required that senior ASB scientists resident in the region devote substantial time to the development and maintenance of informal connections with relevant policy officials. Seldom was effective "boundary spanning" driven from the other side, ie., by local policy makers cultivating relationships with ASB scientists.

Accountability for the collaborative development of research agendas reflecting needs of decision support was provided through a number of channels. Many of these-and not the least powerful — were simply the informal collegiality noted above. A key role was played, however, by those individuals that the ASB labeled "national champions:" individuals, usually scientists, who had managed to secure the respect of both the scientific and policy communities. As a matter of policy, ASB sought to cultivate such individuals and bring them onto its official steering group, thus helping to assure that regional decision support needs would find a voice in the setting of research priorities for the overall program. More formally, the CGIAR convened annual planning workshops at 
the national and regional levels in which ASB participated. At these workshops, scientists and staff advising relevant policy makers collaborated in the development of workplans and research priorities. The tone of these workshops was generally of an advisory rather than governing nature. They were backed, however, by potential hard sanctions: ASB (like all CGIAR programs) needed official government permission to operate in host countries, but also could exit (along with its funding) from countries unwilling to work closely enough with it to achieve desired impacts on practice.

Boundary objects played important roles in assuring that ASB research provided useful decision support to national level decision makers. These included synoptic country reports, specially prepared "policy briefs" on key issues, and models focused at regional scales. A common feature of the most influential boundary objects was their tailoring to local decision makers' needs and language. An especially noteworthy innovation was the "ASB Matrix," a succinct (one page) table summarizing what ASB research had discovered about the tradeoffs among alternative land uses in terms, denominated in economic, social, and environmental indicators reflecting the concerns of policy makers.

\section{Use of Knowledge for Negotiation Support $\left(U_{m}\right)$}

The most complex forms of boundary work we found in the ASB emerged in the context of multiple knowledge users with potentially conflicting objectives and demands for knowledge (col. $U_{m}$ in Table 2). The challenge of creating useful information in such potentially politicized situations included the previously discussed need to assure users of the salience and credibility of knowledge. But this context highlighted the additional need to assure users of the legitimacy (or fairness) of processes for mobilizing knowledge, since each user may seek to harness the authority of knowledge to support its own agenda, while suspecting that each other user is trying to do the same thing. Successful boundary work must therefore develop processes that leave all users convinced that the knowledge production process has not been unfairly biased in support of another's agenda, and thus provides a legitimate (as well as credible and salient) foundation for subsequent negotiations. Failed boundary work can result in one or more parties rejecting a common knowledge base that might have been useful for subsequent negotiations, not because they doubt the credibility or saliency of that knowledge but because they believe that the questions asked or evidence considered may have been stacked unfairly in another's favor.

\subsection{Boundaries between the ASB and Multinational Negotiations $\left(S_{1} U_{m}\right)$}

We encountered several instances of efforts to use ASB research to help resolve conflicts between ministries and other domestic political actors in particular countries. ASB was also active in a number of international processes, including the UNFF and the World Bank's BioCarbon Fund. Perhaps the best example of ASB's boundary work in the SiUm context, however, is provided through the role it played in the Millennium Ecosystem Assessment (MA). This global study, involving over 1300 experts worldwide, was initiated by UN Secretary General Kofi Annan in 2001 "to assess the consequences of ecosystem change for human well-being and the scientific basis for action needed to enhance the conservation and sustainable use of those systems and their 
contribution to human well-being." ASB was asked to be responsible for the component of the MA addressing the tropical forest margins. The ultimate challenge for ASB and other MA participants was to introduce usable scientific information into the often intense conflicts between advocates of biological conservation and of economic development at national and global scales. Most global environmental assessments injected into such potentially divisive political contexts have failed to have much impact, often because they were perceived to be biased toward one user constituency or another, and thus failed to meet the "legitimacy" criterion of Table 1. ASB's contribution to the MA, in contrast, was credited by major stakeholders from all sides of the political debate with creating a credible, salient, and legitimate knowledge base on which to build subsequent negotiations (Clark et al. 2006). We summarize below what we found to be the most significant elements of its relatively successful strategy for boundary work.

Participation: The special challenge of participation in the ASB-MA was to find ways of effectively engaging the enormous range of interested parties, which included individual farmers in the ASB benchmark sites, ministerial users from multiple nations, representatives of diverse global organizations, and scientists working at all scales. In the face of potentially crippling supply of interested stakeholders, ASB-MA adopted a strategic approach to engagement. For scientists, it drew on the 250 researchers from 50 institutions around the world who had been involved in ASB research, and complemented those with an open call to qualified experts for expressions of interest in participating in the assessment. From this pool, the assessment selected scientists from a strategic mix of countries, disciplines, and institutions (including universities, national agricultural research systems, NGOs, and international programs). Needs of local users were systematically identified through community level assessments regularly conducted at each of the ASB benchmark sites, supplemented by surveys conducted especially for the assessments. Finally, ASB-MA conducted consultations on user needs with policy shapers at the subnational and national level throughout ASB's domain.

Accountability: The ASB-MA faced two special challenges of accountability. First, the participants in the ASB research program itself needed assurances that their findings made it into the Millennium Assessment without distortion. Second, global users from both the conservation and development communities needed assurances that the assessment was not biased toward the action agenda of either. ASB-MA provided such assurances by subjecting itself to the parallel but separate governance structures of the ASB and MA, respectively. Accountability to the ASB was achieved through discussion and approval of the ASB-MA by ASB's Global Steering Group. This included representatives of both participating international research programs of the CGIAR and relevant national agricultural research organizations from ASB's host countries. Accountability to the MA was achieved through formal approval of the ASB-MA as an official component of the Millennium Ecosystem Assessment by the MA Board. This included representatives of both development organizations and conservation organizations. No formal linkage between the ASB and MA governance mechanisms was sought or achieved, though one of the conditions for authorization of the ASB-MA by the MA Board was the existence of a broadly representative governing body for ASB, a role convincingly played by the ASB Global Steering Group. 
Boundary Objects: The principal boundary object created by the ASB-MA was simply its assessment report "Forest and Agroecosystem Tradeoffs in the Humid Tropics." This document — and the process that commissioned, produced, and reviewed it—effectively spanned the worlds of policy-driven concerns and science-based findings. Many subsidiary products of the assessment also served as boundary objects on narrower topics - for example the "policy briefs" prepared on particular topics such as restoration of degraded landscapes and the forces driving tropical deforestation. The "ASB Matrix" that played such a prominent role as boundary object in the $\mathrm{S}_{1} \mathrm{U}_{1}$ context noted earlier was also effectively used in the ASB-MA.

\subsection{Boundaries between Multiple Knowledge Sources and Multiple Users $\left(\mathbf{S}_{\mathbf{n}} \mathbf{U}_{\mathbf{m}}\right)$}

The most novel, challenging, and complex instances of boundary work we found in ASB are those addressing the challenges characteristic of the lower right corner of Table 2: multiple sources of knowledge $\left(S_{n}\right)$ used in support of negotiations among multiple stakeholders $\left(\mathrm{U}_{\mathrm{m}}\right)$. We will argue in the Discussion section of this paper that such contexts are likely to be more the rule than the exception for research programs seeking to support sustainable development. For ASB, they were ubiquitous. To illustrate how ASB structured its boundary work in such situations, we summarize here our findings on the program's efforts to facilitate sustainable development in the forests of Indonesia's Sumberjaya region.

Sumberjaya is an upland area of southeast Sumatra originally covered in rainforest, but later with substantial tracts converted by small farmers to coffee production. Beginning in the 1970s, however, local and state governments increasingly expressed concern that the expansion of coffee farming was endangering downstream watershed services. Lands were therefore increasingly classified as state "protective" forests, with the early 1990s seeing intensifying conflict around a series of police actions to evict small farmer "encroachers." Government reforms followed, centered on community forest management with new rules of forest tenure (Hutan Kemasyarakatan, or HKm), conditioned on farmers meeting a complex set of management requirements. Implementation, however, was slow, based in part on farmers' mistrust of government, and in part on the lack of agreed upon management practices that would meet goals of both watershed conservation and agricultural development. ASB (and later its spin-off program "Rewarding the Upland Poor for Environmental Services" or RUPES, both operating under ICRAF) persuaded the local government to allow it to help experiment with different $\mathrm{HKm}$ conditionality requirements in order to achieve better results (Colchester et al. 2005).

ASB-RUPES rapidly discovered, however, that merely conducting research to discover the relevant facts in its customary decision support mode was inadequate. As two of us wrote at the time, "The real-world human impact on natural resources derives from a large number of individual decisions, made with different access to sources of knowledge and information, with different technical means to organize exploitation, and with different objectives, constraints, priorities, and strategies. The best we can hope for is a process of negotiations among stakeholders that leads to modification of the individual 
decisions to produce superior outcomes from the broader social perspective" (van Noordwijk et al. 2001). ASB-RUPES therefore began to develop a new mode of engagement for its work in Sumberjaya, which it eventually called "negotiation (rather than decision) support." The approach did involve a significant amount of classic agroforestry research and development, but also found that it needed to include unconventional elements of capacity building and mediation. Four years into this engagement, an independent analysis documented that the new, ASB-RUPES facilitated, $\mathrm{HKm}$ program had made a significant contribution to sustainable development in Sumberjaya (Pender et al. 2008; see also Colchester et al. 2005). Our work suggests that several novel features of ASB-RUPES' boundary work contributed to this success.

Participation: History had left a deep legacy of distrust among the various stakeholders in the management of Sumberjaya forests: small holders, regional government officials, NGOs, and forestry experts from the national government). ASB-RUPES diagnosed that providing support to only one of these stakeholders it - along with its research resultswould almost certainly be dismissed as just another advocate picking sides in the continuing conflict. It therefore devoted substantial effort to cultivating relationships with each of the major stakeholders, listening to their questions, treating their knowledge and beliefs respectfully but critically, and eventually bringing them together in carefully "neutral" meetings and workshops that produced shared knowledge.

Accountability: The same deficit of trust noted above meant that there existed no domestic institution that all of the contending parties would accept as guarantor of ASBRUPES' efforts. The program therefore invested in a variety of bi-lateral but largely transparent confidence building measures, meant to assure each stakeholder individually of the salience, credibility, and above all legitimacy (even-handedness) of ASB-RUPES' efforts. By all accounts this worked remarkably well, drawing in no small part on the reputation in the region of the program's "parent" ICRAF (World Agroforestry Centre). But its success was clearly much more dependent on the commitment and reputation of a few key individuals than on any formal institutional mechanism. These leaves open the question of whether and how the boundary work of ASB-RUPES can be sustained over the long run as personnel change. On the other hand, it may be that the formal legal status of the new HKm conditional tenure agreements facilitated by ASB-RUPES (see below) can carry much of the weight of accountability into the future. In that case, the crucial contribution of the program will have been a transient one of capacity building.

Boundary Objects: Multiple boundary objects were created to stabilize parts of ASBRUPES' engagement in the Sumberjaya community forestry effort. These included conventional things such as shared research and measurement protocols (mostly with the national forestry experts), maps (with the farmers and district officials), and models of best practice. Most significant and unusual, however, was the HKm agreement itself, and the community forestry permits that flowed from it. These created a formal and legally binding framework of expectations and obligations that all stakeholders in the process bought into. The crucial contribution from ASB-RUPES was its finding that coffee farms and mixed use trees could meet both the income goals of farmers and the conservation goals of government. All parties were initially skeptical of this. But ASB-RUPES 
participatory and transparent research approach changed minds, and thus created the key "win-win" option that made the new HKm system work. From the perspective of the stakeholders, the resulting $\mathrm{HKm}$ arrangements constituted a simple, fair contract system. But for the purposes of this study, they serve the same "boundary object" role more conventionally assigned to maps, models, and protocols.

\section{Discussion}

Our study has evaluated the applicability of "boundary work" concepts-largely elucidated in the context of western science and science-policy debates-for understanding efforts to harness research for the advancement of natural resource management in the developing world. Others have also begun to explore such questions (Agrawala 2001; Carr and Wilkinson 2005; Mollinga 2008). Nonetheless, a recent comprehensive survey conducted under the auspices of the Overseas Development Institute (ODI) concluded that despite a broad consensus on the need for boundary work in strengthening science-policy dialogue in developing countries, there is no consensus on how boundary work is actually carried out, or on how its effectiveness can be improved (Jones et al. 2008).

We conclude that much of that lack of consensus is almost certainly due to an insufficiently differentiated view of the different kinds of boundary work actually being performed. Explanations that may be true in some kinds of boundary work but not others are thereby confounded, with the resulting appearance of disagreement. We have shown that there is in fact a substantial but structured variety of boundary work being performed even within the context of natural resource management activities of one program of one international research organization. We devised here a conceptual framework (Table 2) suggesting that much of the observed variety can be understood in terms of the sources and uses of knowledge that boundary work engages. This framework captures not only our own experience with the ASB program, but also much of the variety of boundary work we have encountered in our own research and the literature.

\subsection{Differentiated Challenges of Boundary Work}

In particular, our analysis suggests that the intended use of knowledge (the columns of Table 2) imposes different demands on (and criteria for) successful boundary work strategies.

Enlightenment (Uo): Where the intended use is simply enlightenment, the principal challenge of boundary work is to construct a perception on all side of the boundary of the credibility of the knowledge so produced. This covers the classic "demarcation" of science from non-science (S1Uo) as originally described by Gieryn (1983; 1999) and generally pursued through strategies of peer review. It also turns out to be the principle challenge faced by efforts seeking to advance understanding by bringing together multiple kinds of knowledge (SnUo), whether through interdisciplinary scientific research (Mollinga 2008) or the integration of indigenous and scientific knowledge (Reid et al. 2009). 
Decision (U1): Where the intended use of knowledge is the support of decision making by a single, relatively autonomous agent, the challenge of boundary work expands to include shaping not only the credibility but also the saliency of knowledge. In cases of a single source of relevant expertise (S1U1), this applies to what has been called "client oriented advising" (Andrews 2002, 12) as well as to the long tradition of scientific advice to leaders in government (Golden 1991). The challenge remains essentially the same, if the solutions are more complicated, where there are multiple sources of knowledge but still single decision makers (SnU1), as in so-called "farming systems research" and other participatory forms of analysis in which decision makers take an active role (Andrews 2002, 12; Carr and Wilkinson 2005; Buizer et al. 2010).

Negotiation (Um): Finally, where the intended use of knowledge is to inform negotiation among participants in seriously politicized contexts, the challenge of boundary work widens once again to include not only the establishment of the credibility and saliency of knowledge, but also its legitimacy. Relatively well understood is the case (S1Um) where potentially conflicted parties may seek out a single authoritative source of knowledge in the form of scientific assessments such as the IPCC or Millennium Ecosystem Assessment (Zehr 2005; Mitchell et al. 2006). More complex are the cases (SnUm) in which multiple parties are likely to mobilize the knowledge sources that support their particular interests, and the role of boundary work is to move beyond the resulting politicization of science to shape a broadly accepted common knowledge base to support negotiations (van Noordwijk 2001).

This last case-SnUm in our framework, or what others have called "participatory joint fact-finding" (Andrews 2002) — can be seen as not only the most difficult but also the most general context for boundary work. All the others described here and captured in Table 2 can be thought of as limiting cases of SnUm in which either the number of competing sources of knowledge or the number of competing political interests in the use of knowledge have been reduced.

\subsection{Differentiated Strategies of Boundary Work}

The conceptual framework for boundary work summarized in Table 2 is also useful for sorting out what Jones et al. (2008) correctly characterize as the "lack of consensus" about appropriate strategies in the literature on boundary work. We discuss our findings below under headings reflecting the three key attributes of successful boundary work hypothesized from experience in the western world.

Participation: Our study confirms the general contention that effective boundary work requires meaningful participation of key actors from each of the communities (potentially) divided by the boundary. But who constitutes the "key actors" differed with context in ways determined by the use and source of knowledge involved, i.e., by the position of the boundary work in the framework of Table 2. Moreover, the successful strategies for engaging meaningful participation varied along the same dimensions. Thus, in one case within the SnUo context, all the key participants were research scientists, albeit from different and sometimes apparently incompatible disciplinary traditions. Initial tensions growing from different research styles and questions of 
interest were effectively bridged by formal commitments - brokered by ASB using both wage contracts and intellectual excitement as incentives - for scientists from all disciplines to work together on common problems (e.g., the ASB Thematic Working Groups). In contrast, in the highly politicized multi-user context of SnUm, ASB found that its boundary work needed to bring together not only CGIAR scientists from multiple disciplines, but also hill farmers, regional politicians, and national forestry experts. The bridges forged among these groups were less formal than in the SnU1 case. They were also highly pragmatic, with the potential chaos of multistakeholder debates circumvented through a boundary work strategy built around a series of bi-lateral engagements between ASB and each of the other actors. Key to securing appropriate participation in all contexts, however, was the commitment of ASB to do so: its decision to define its role and commit its resources to act as a proactive boundary organization was utterly essential to the successful conduct of boundary work in all of the contexts we encountered.

Governance: The western literature emphasizes the importance of formal governance arrangements to make boundary work "accountable" to the different communities involved. In contrast, the ODI survey of developing countries noted earlier found relatively little concern over governance of science-policy interactions (Jones et al. 2008). In our studies of ASB we observed very different emphases on and approaches to governance depending on the context of the boundary work being performed. In the context of expert advice to government (S1U1), ASB found itself helping to create and strengthen a boundary separating the expert and political roles of civil servants in national forestry and agricultural ministries. These individuals, though often excellent scientists, had few professionally safe means of separating what they knew as scholars from what regulations required them to teach as civil servants. But providing an independent group of science peers for these civil servants, ASB provided a "safe space" within which they could differentiate their roles. In other cases, particularly in dealing with external donors to ASB research (Uo), accountability arrangements were indeed in place and formal, but tended to assure that donors interests rather than necessarily the interests of local users were secured. In highly politicized contexts (Um), there were virtually no formal accountability arrangements, almost certainly reflecting the lack of institutions that could have enforced them. Once again, the principal reason that boundary work succeeded was simply ASB's own deep commitment to make it work. This meant holding itself accountable to other stakeholders in the system, rather than relying on external mechanisms to assure such accountability.

Boundary Objects: The literature led us to expect a plethora of boundary objects to be associated with successful boundary work. We indeed documented a great variety of ways in which agreements among different communities on questions, data, and conclusions were stabilized in shared forms. Several of the kinds of boundary objects we observed showed up in multiple contexts, for example maps, models, and even the ASB matrix of tradeoffs among alternative land uses. Examined more closely, however, the dominant finding of our work on boundary objects is how finely the successful ones are tailored to their specific contexts. Thus one of the most complex boundary objects we found - the HKm community forestry agreement from ASB's Indonesia site (SnUm) - is unique to its circumstances. And the "models" that show up almost everywhere are in 
fact computable models in the context of boundary work across disciplines (SnUo), physical models at the boundary of researchers and farmers (SnU1), and scaleappropriate conceptual models when used in science advice to policy makers (S1U1). A similar pattern holds for maps that show up as important boundary objects, but in quite different forms, across the multiple use and source contexts we observed. Arguments about whether "maps" or "models" or "contracts" are significant boundary objects are therefore less informative than ones about the "fit" of particular maps, etc., to the context in which they are deployed.

\subsection{Generalized Findings}

Beyond the context dependent findings discussed above, we found that an essential contribution of boundary work in the rural development contexts we examined was simply building capacity to articulate users' demand for technical information on the one hand, and to transmit technical information back into the "field" on the other. Both of these functions are taken for granted in most of the literature on boundary work. Beyond this general need to build capacity we found two specific challenges facing boundary work in the rural development situations that were, if not absent, at least much less evident in the existing western models with which we began.

The first of these was the need for boundary work to integrate multiple forms of knowledge, in particular the contextualized knowledge of practice with the generalized knowledge emerging from laboratories and field experiments. It became immediately clear through our field work that much of the knowledge needed to inform effective action in our rural development cases was of the former sort. Formal, generalized knowledge from international research programs equally clearly had a potential contribution to make, but only if it could be integrated with - rather than displace - the enormously rich contextual knowledge of people living on and working the relevant landscapes. This integration posed significant problems not only of communication and translation, but also of epistemology (e.g., how to combine "uncertainty" estimates of farmers with those of lab scientists). Successful boundary work in our rural development contexts needed to make these problems much more central to its activities than seems to have been the case for most western models we examined.

A second special challenge facing boundary workers in rural development situations was the extreme politicization of formal knowledge. The relationship between knowledge and power is not, of course, unremarked in the existing literature on boundary work. Nonetheless, both the fact and the presumption that formal (scientific) knowledge was being used as an instrument of state and business interests to control development activities of rural land users were central features of the reality we encountered in our field work. The demands on boundary work and workers actively to construct the legitimacy of formal knowledge in the eyes of rural land users were thus much greater than those we had encountered in existing western case studies. The very dominance of

politics that created such demands meant that they could seldom be met overtly. As a result, much of the responsibility for effective boundary work, especially in the more highly politicized contexts we encountered, was born by individuals rather than 
organizations, acting at some risk to themselves below the horizon of official acts and arrangements.

We conclude from our studies that boundary work can be most generally conceived of as "negotiation support" institutions that are overtly engaged in the work of constructing both usable knowledge itself and the social order that creates and utilizes that knowledge. The design of boundary organizations in "decision support" mode that is stressed in much of the literature derived from developed country examples can be seen as a recognizable and important sub-set of such a general "negotiation support" formulation, and one that is almost certainly adequate when parties involved in the creation and use of knowledge have approximately equal political power or democratic access to the control of power. For the extremely asymmetric cases of power distribution that characterized our (and others') rural development cases, however, the explicit attention to managing power contained in the negotiation support formulation appears to be essential to the effective and democratic functioning of boundary organizations. This finding confirms and generalizes our earlier work on the importance of negotiation functions in particular cases of boundary work, and is compatible with the broader views of STS and "Mode 2 knowledge" theorists on the inescapable intercalation of knowledge and socio-political order. Its practical implications for the conceptualization and design of effective boundary organizations are nonetheless substantial, and constitute a major departure from the apolitical, one-directional "transfer" models that still inform much of the dialogue and practice of science-for-development.

Our continuing work on this topic suggests that our findings about the determinants of successful boundary work in the ASB seem likely to hold for many other cases of boundary work reported in the literature, and thus to offer potentially useful guidance for general strategies to promote more effective linking of knowledge with action for sustainability. The principal policy implication of our work is that improving the ability of global research programs to produce useful knowledge for sustainable development will require both greater and differentiated support for multiple forms of boundary work.

\section{Methods}

The findings reported here are derived from three principle sources of data.

The first is an independent assessment of the first decade of ASB experience, carried out by a team led by one of us (WCC) at the request of the Science Council of the CGIAR. This involved field visits to several ASB sites, interviews with 74 scientists, farmers, national officials, and advocates involved with the program, and extensive analysis of archival records. A modified version of the "Results based management" approach developed by the Canadian International Development Agency (CIDA 1996) was used to document impact and evaluate success. The full method and data are published (Clark et al. 2006).

The second is a systematic self-assessment run by one of us, Thomas Tomich, involving 42 ASB researchers in an on- line consultation. This was structured following an analytical framework on "harnessing science and technology for sustainability" 
developed by Harvard University researchers based on their studies of other comparable cases. This analytical framework includes four dimensions of integration (disciplinary, functional, spatial/temporal, and knowledge) and related challenges of institutional learning and adaptation, fostering appropriate participation, and managing resource and capacity constraints. A special website was developed for ASB's virtual consultation, which was professionally facilitated. This innovative use of information technology proved to be an effective means of triangulating perceptions of spatially dispersed researchers. Electronic polling was used to identify areas of consensus or broad agreement, as well as areas where views diverged. The cases of divergence received special attention in open ended 'virtual' discussions. Full results and methodology have been published (Tomich et al. 2007).

The third is a recently completed field project examining the practices and evaluating the outcomes in the CGIAR's program called "Rewarding Upland Poor for Environmental Services" (RUPES), a spinoff of the ASB. The research project consisted of an initial workshop in the fall of 2006 comprised primarily of scholars engaged in the research of boundary theory, organizations, and work. In this workshop we formalized our understanding of the research questions and developed our initial protocol. Members of the team conducted research at several RUPES locations in Indonesia in 2007 involving archival research, semi-structured interviews, and focus groups with farmer groups; local and regional elected leaders; researchers and field workers from RUPES and ICRAF; local, regional, and national representatives from the Ministry of Forestry and its extension workers; officials from hydroelectric companies; representatives from local and international NGOs involved in the project. We also co-hosted an additional workshop with Brawijaya University in Malang, East Java, comprised primarily of practitioners, NGOs, and government officials in addition to a few scholars of boundary work. (McNie et al. 2008).

The purpose of this workshop was to 'truth test' our findings from the fieldwork with those involved in the agroforestry and watershed sustainable development activities. Participants provided feedback and analysis of our research findings and also received training on boundary theory and work. Analysis of the data occurred in 2007 and 2008, culminating in an additional workshop at the Annual Meeting of the American Association for the Advancement of Science in February 2009. The session offered our research team an opportunity to 'close the loop', sharing our findings with scholars of boundary theory and work and of sustainability science. Full results are being prepared for publication. Some of the data collected are utilized here for the first time. 


\section{References}

Agrawala, Shardul, Kenneth Broad, and David H. Guston. 2001. Integrating climate forecasts and societal decision making: Challenges to an emergent boundary organization. Science, Technology, and Human Values 26 (4): 454-77.

Andrews, Clinton J. 2002. Humble analysis: The practice of joint fact-finding. Westport, CT: Praeger.

ASB. ASB partnership for the tropical forest margins: About ASB. 2010. Available from http://www.asb.cgiar.org/about_us/.

Buizer, James, Katherine Jacobs, and David Cash. 2010. Making short-term climate forecasts useful: Linking science and action. Proceedings of the National Academy of Sciences: doi:10.1073/pnas.0900518107.

Canadian International Development Agency. 1996. Results-based management in CIDA: Policy statement. Ottawa, Canada: CIDA.

Carr, Anna, and Roger Wilkinson. 2005. Beyond participation: Boundary organizations as a new space for farmers and scientists to interact. Society and Natural Resources 18: 255-65.

Cash, David W., William C. Clark, Frank Alcock, Nancy M. Dickson, Noelle Eckley, David H. Guston, Jill Jäger, and Ronald B. Mitchell. 2003. Knowledge systems for sustainable development. Proceedings of the National Academy of Sciences 100 (14): 8086-91.

CGIAR. CGIAR: Who we are. 2010]. Available from http://www.cgiar.org/who/index.html;.

CGIAR. Task Force on Natural Resource Management. 2000. Integrated natural resource management research in the CGIAR: A brief report on the INRM workshop held in Penang, Malaysia, 21-25 August 2000. Washington, DC: CGIAR, http://www.cifor.cgiar.org/Knowledge/Publications/Detail?pid=882.

Clark, William C., A. Contreras, and K. Harmsen. 2005. Report of the external review of the systemwide programme on alternatives to slash-and-burn (ASB): Evaluation and impact assessment of the ASB Programme. Washington, DC: CGIAR Science Council Secretariat, FAO, http://www.cgiar.org/pdf/agm08/agm08 independent_review_synthesis_report.pdf.

Colchester, Marcus, Andree Ekadinata, Chip Fay, Gamal Pasya, Indriani E., Lisken Situmorang, Martua Sirait, et al. 2005. Facilitating agroforestry development through land and tree tenure reforms in Indonesia: Impact study and assessment of the role of ICRAF. Bogor, Indonesia: ICRAF Southeast Asia, 2, http://www.icraf.cgiar.org/sea.

Evans, Robert. 2005. Introduction: Demarcation socialized: Constructing boundaries and recognizing difference. Science, Technology and Human Values 30 (1): 3-16.

Gieryn, T. 1999. Cultural boundaries of science: Credibility on the line. Chicago, IL: University of Chicago Press.

1983. Boundary work in professional ideology of scientists. American Sociological Review 48: 781-95. 
Golden, William, ed. 1991. Worldwide science and technology advice to the highest levels of governments. New York: Pergamon.

Guston, David H. 2001. Boundary organizations in environmental policy and science: An introduction. Science, Technology, and Human Values 26 (4): 399-408.

Habermas, J. 1971. Theorie und praxis. Frankfurt am Main: Suhrkamp.

Hellström, Tomas, and Merle Jacob. 2003. Boundary organisations in science: From discourse to construction. Science and Public Policy 30 (4): 235-8.

International Council for Science, Initiative on Science and Technology for Sustainability, and Third World Academy of Sciences. 2002. Science and technology for sustainable development. Paris: ICSU, ICSU Series on Science for Sustainable Development, No 9.

Jasanoff, Sheila. 1990. The fifth branch: Science advisors as policymakers. Cambridge, MA: Harvard University Press.

Jones, Nicola, Harry Jones, and Cora Walsh. 2008. Political science? Strengthening sciencepolicy dialogue in developing countries. Overseas Development Institute, Overseas Development Institute Working Paper 294.

Lindblom, Charles Edward, and David K. Cohen. 1979. Usable knowledge: Social science and social problem solving. New Haven: Yale University Press.

McNie, Elizabeth, Meine van Noordwijk, William C. Clark, Nancy M. Dickson, Niken Sakuntaladewi, Suyanto, Laxman Joshi, Beria Leimona, Kurniatun Hairiah, and Noviana Khususiyah. 2008. Boundary organizations, objects and agents: Linking knowledge with action in agroforestry watersheds. Report of a Workshop held in Batu, Malang, East Java, Indonesia, 26-29 July 2007. CID Graduate Student and Research Fellow Working Paper No. 34. Joint Center for International Development and World Agroforestry Centre (ICRAF-Southeast Asia) Working Paper, Cambridge, MA: Harvard University and Indonesia: ICRAF-Southeast Asia.

Merton, Robert K. 1957. Social theory and social structure. Glencoe, Illinois: Free Press.

Mitchell, Ronald B., William C. Clark, and David W. Cash. 2006. Information and influence. In Global environmental assessments: Information and influence, eds. Ronald B. Mitchell, William C. Clark, David W. Cash and Nancy M. Dickson, 307-338. Cambridge, M.A.: MIT Press.

Mollinga, Peter P. 2008. Boundary work: Challenges for interdisciplinary research on natural resource management. Presented at Habilitationskolloquium, Faculty of Agriculture Council Meeting at Bonn University, 26 Nov. 2008.

National Research Council. 2006. Linking knowledge with action for sustainable development: The role of program managers. Washington, DC: National Research Council, Roundtable on Science and Technology for Sustainability.

Palm, Cheryl A., Stephen A. Vosti, Pedro A. Sanchez, and Polly J. Ericksen, eds. 2005. Slashand-burn agriculture: The search for alternatives. New York: Columbia University Press. 
Pender, John, Suyanto, John Kerr, and Edward Kato. 2008. Impacts of the Hutan Kamasyarakatan social forestry program in the Sumberjaya watershed, West Lampung district of Sumatra, Indonesia. Washington, DC: International Food Policy Research Institute, 00769, http://www.ifpri.org/publication/impacts-hutan-kamasyarakatan-socialforestry-program-sumberjaya-watershed-west-lampung-d.

Raman, Sujatha. 2005. Introduction: Institutional perspectives on science-policy boundaries. Science and Public Policy (SPP) 32 (6) (12): 418-22, http://search.ebscohost.com/login.aspx?direct=true $\& \mathrm{db}=a p h \& A N=19503148 \&$ site=ehostlive\&scope $=$ site.

Reid, R. S., D. Nkedianye, M. Y. Said, D. Kaelo, M. Neselle, O. Makui, L. Onetu, et al. 2009. Evolution of models to support community and policy action with science: Balancing pastoral livelihoods and wildlife conservation in savannas of East Africa. Proceedings of the National Academy of Sciences (November 3).

Sanchez, Pedro A., Cheryl A. Palm, Stephen A. Vosti, Thomas P. Tomich, and Joyce Kasyoki. 2005. Alternatives to slash and burn: Challenge and approaches of an international consortium. In Slash-and-burn agriculture: The search for alternatives, eds. Cheryl A. Palm, Stephen A. Vosti, Pedro A. Sanchez and Polly J. Ericksen, 3-40. New York: Columbia University Press.

Star, Susan Leigh, and James R. Griesemer. 1989. Institutional ecology, 'translations' and boundary objects: Amateurs and professionals in Berkeley's museum of vertebrate zoology, 1907-39. Social Studies of Science 19 (3): 387-420.

Tomich, Thomas P., Dagmar W. Timmer, Sandra J. Velarde, Julio Alegre, Veronika Areskoug, David W. Cash, Andrea Cattaneo, et al. 2007. Integrative science in practice: Process perspectives from ASB, the partnership for the tropical forest margins. Agriculture, Ecosystems and Environment 121 (3) (07): 269-86, http://search.ebscohost.com/login.aspx?direct=true $\& \mathrm{db}=a p h \& A N=24382643 \&$ site $=$ ehostlive\&scope $=$ site.

van Noordwijk, Meine, T. P. Tomich, and B. Verbist. 2001. Negotiation support models for integrated natural resource management in tropical forest margins. Conservation Ecology [Online] 5 (2): 21.

World Bank. 1998. World development report 1998-1999: Knowledge for development. Washington, DC: World Bank.

Zehr, Stephen. 2005. Comparative boundary work: US acid rain and global climate change policy deliberations. Science and Public Policy (SPP) 32 (6) (12): 445-56, http://search.ebscohost.com/login.aspx?direct=true $\& \mathrm{db}=\mathrm{aph} \& \mathrm{AN}=19503150 \&$ site=ehostlive\&scope $=$ site. 